\section{Oxyfluorfen Strongly Affects Larix occidentalis but Minimally Affects Sagina procumbens in a Bareroot Nursery}

\author{
R. Kasten Dumroese ${ }^{1}$ \\ U.S. Department of Agriculture, Forest Service, Rocky Mountain Research \\ Station, 1221 South Main Street, Moscow, ID 83843
}

Jasmine L. Williams

U.S. Department of Agriculture, Forest Service, Idaho Panhandle National

Forest, Coeur d'Alene Nursery, Coeur d'Alene, ID 83815

\author{
Jeremiah R. Pinto \\ U.S. Department of Agriculture, Forest Service, Rocky Mountain Research \\ Station, 1221 South Main Street, Moscow, ID 83843
}

\section{Peng Zhang \\ Northeast Forestry University, School of Forestry, No. 26 Hexing Road, Harbin, 150040 China}

Additional index words. biomass, canopy cover, Larix occidentalis, postemergence, preemergence, Sagina procumbens, seedling emergence

\begin{abstract}
Our objective was to evaluate oxyfluorfen for control of birdseye pearlwort (Sagina procumbens L.) in a bareroot nursery crop of western larch (Larix occidentalis Nutt.) seedlings. Oxyfluorfen applied at rates up to $0.56 \mathrm{~kg}$ a.i./ha in a split-plot experiment with combinations and frequencies of pre- and postemergence sprays gave minimal control of birdseye pearlwort. Although preemergence rates $0.42 \mathrm{~kg}$ a.i./ha or greater reduced western larch emergence $10 \%$ compared with the control, final seedling inventory was similar for rates $0.42 \mathrm{~kg}$ a.i./ha or less. Seedlings receiving $0.42 \mathrm{~kg} \mathrm{a} . \mathrm{i}$./ha or greater grew $30 \%$ more biomass than those that received $0.28 \mathrm{~kg}$ a.i./ha or less. When applied postemergence, oxyfluorfen reduced the number of larch seedlings at final inventory $9 \%$ and those seedlings had $20 \%$ less biomass than the control. Oxyfluorfen applied preemergence increased the amount of bare soil (reduced the weed canopy) throughout the production cycle compared with the control but even the most efficacious treatment combinations still had birdseye pearlwort canopy coverage $63 \%$ or greater.
\end{abstract}

Received for publication 3 Feb. 2014. Accepted for publication 2 Mar. 2014.

This work was funded by the U.S. Department of Agriculture, Forest Service, National Center for Reforestation, Nursery, and Genetic Resources, the Coeur d'Alene Nursery (Region 1), and the Rocky Mountain Research Station.

Mention of a trademark, proprietary product, or brand names does not constitute a guarantee or warranty of the product by the U.S. Department of Agriculture and does not imply its endorsement or approval to the exclusion of other products that also may be suitable.

We thank Aram Eramian and Brian Flynn at the Coeur d'Alene Nursery for their assistance with overall crop production and application of the treatments; and Eric Doubet, Jake Kleinknecht, Janelle Meier, and Yan Zhu for sample collection and processing; and Amy Ross-Davis for statistical analyses. We also thank Vanelle Peterson, Senior Research Biologist, Dow AgroSciences; Lawrence W. Lass, Research Support Scientist, University of Idaho; and Garrett E. Crow, Professor Emeritus, University of New Hampshire, for consultations.

${ }^{1}$ To whom reprint requests should be addressed; e-mailkdumroese@fs.fed.us.
In bareroot nurseries used to produce conifer seedlings for reforestation, production is hampered by weeds. Fumigation, hand treatments, mechanical treatments, and herbicides can all be used to control weeds; herbicides are particularly cost-effective (South and Gjerstad, 1980a). To maximize germination and early growth of desired seedlings, bareroot beds are often treated with pre- and postemergence herbicides immediately after sowing (South and Gjerstad, 1980b). One such herbicide is oxyfluorfen. This diphenyl-ether herbicide is strongly adsorbed on soil, not readily desorbed, and shows negligible leaching with a half-life of 30 to $40 \mathrm{~d}$ (South and Gjerstad, 1980b). Oxyfluorfen inhibits protoporphyrinogen oxidase in the chloroplast and leads to cell membrane disruption. It is commonly used to control broadleaf vegetation in agricultural crops (Daugovish et al., 2008; Doohan and Felix, 2012) and bareroot nurseries in which a wide variety of woody species are grown for reforestation and conservation (e.g., South, 1984). In forest nurseries, oxyfluorfen can reduce the need for hand-weeding in pine crops by up to $76 \%$ (Sloan and Thatcher, 1988). Western larch (Larix occidentalis Nutt., hereafter referred to as larch) seedlings have been reported, however, to be more sensitive to herbicides than pines (Pinus L.) or true firs (Abies Mill.) (Boyd, 1984; Duncan et al., 2008). This is unfortunate because larch is a valued timber species with productivity rivaling other species within its range that includes the Intermountain Region of western North American, specifically the northern portions of the Cascade and Rocky Mountain ranges in the United States and southern Canada (Schmidt and Shearer, 1990).

Birdseye pearlwort (Sagina procumbens L., hereafter referred to as pearlwort) is a common, difficult-to-control weed in container nurseries across the United States (Altland, 2013; Judge et al., 2005). Some indicate this perennial, herbaceous weed is native to several Canadian provinces (USDA NRCS, 2013), whereas others show it native to Europe (FNA, 2005). Regardless, it is now widespread across the United States except in areas where soil conditions are less favorable (not cool and moist): Prairie states, the desert Southwest, and the Gulf Coast states (Midwest Weeds, 2013; USDA NRCS, 2013). Pearlwort is a low-growing stoloniferous perennial with linear, awl-like, fleshy leaves on slender stems. It produces prodigious amounts of greenish white flowers (Midwest Weeds, 2013). In at least one bareroot forest nursery in the Pacific Northwest, pearlwort has become a problematic weed. Its robust growth in early spring, particularly when cool and wet weather predominates, allows it to overtop emerging, slower-growing crop seedlings. If the desired crop seedlings are not directly overtopped and killed, pearlwort reduces seedling growth through resource competition. A single plant averages 4600 seeds, although some plants can generate more than 26,000 seeds (Salisbury, 1976) that can be dispersed 40 to $75 \mathrm{~cm}$ (Altland, 2006). These tiny seeds $(0.3 \mathrm{~mm}$ diameter) can form an extensive seedbank in terms of number (greater than 30,000 seeds $\left./ \mathrm{m}^{2}\right)$, depth $(10 \mathrm{~cm})$, and longevity $(7+$ years) (Akinola et al., 1998; Pakeman and Small, 2005).

Because of the limited work done with pearlwort in bareroot nurseries and its deleterious effects on emerging conifer seedlings, nursery managers were interested in whether oxyfluorfen could be safely used in larch crops to control pearlwort. Some work with Japanese larch [Larix kaempferi (Lam.) Carrière] suggests it could have merit (Abrahamson and Jares, 1984). Our research objectives were to investigate 1) the effects of oxyfluorfen on larch seedling emergence and growth when applied preemergence and postemergence; and 2) the subsequent efficacy of oxyfluorfen to control pearlwort.

\section{Materials and Methods}

This study was conducted at the U.S. Department of Agriculture (USDA), Forest Service nursery in Coeur d'Alene, ID (lat. 
$47^{\circ} 43^{\prime} 2^{\prime \prime} \mathrm{N}$, long. $116^{\circ} 49^{\prime} 34^{\prime \prime} \mathrm{W}, 688$ m elevation). The nursery is on an outwash terrace of glaciofluvial deposits. The Marble series soil (mixed, mesic, Lamellic Xeropsamments) is a coarse sandy loam to a depth of $44 \mathrm{~cm}$ with an overall depth to gravel of $107 \mathrm{~cm}$ (Soil Survey Staff, 2011) having a plow layer $\mathrm{pH}$ of 6.9 and an organic matter content of $2.5 \%$ (A. Eramian, personal communication). During Sept. 2010, the field was fumigated with dazomet (Basamid ${ }^{\circledR}$ G Granular Soil Fumigant; Certis USA LLC, Columbia, MD) at $390 \mathrm{~kg}$ a.i./ha following label directions. On 1 June 2011, larch seeds (seedlot LAOC6960, Kootenai National Forest, lat. $48^{\circ} 53^{\prime} 48^{\prime \prime} \mathrm{N}$, long. $115^{\circ} 43^{\prime} 17^{\prime \prime} \mathrm{W}, 1310 \mathrm{~m}, 92 \%$ germination, $96 \%$ purity) that had been stratified $28 \mathrm{~d}$ were operationally sown with a J.E. Love/ Oyjord seeder (J.E. Love Co., Garfield, WA) into eight formed nursery beds at a rate, based on the germination test, to yield 345 seedlings per running meter of nursery bed at final inventory. Seeds were sown in seven rows $15 \mathrm{~cm}$ apart. Each bed was $1.2 \mathrm{~m}$ wide by at least $113 \mathrm{~m}$ long with $46 \mathrm{~cm}$ between beds. Immediately after sowing, beds were mulched with EcoFibre ${ }^{\circledR}$ hydromulch $\left(3.7 \mathrm{~L} \cdot \mathrm{m}^{-2}\right.$; Profile Products, LLC, Buffalo Grove, IL) and irrigated.

Treatments. Our split-split-plot experiment was applied with four replications. The whole plot treatment was oxyfluorfen $\left(\mathrm{Goal}^{\circledR} 2 \mathrm{XL}\right.$; Dow AgroSciences, Indianapolis, IN) applied preemergence on 3 June over the larch seeds at four rates: $0,0.28,0.42$, and $0.56 \mathrm{~kg}$ a.i./ha. These rates follow label recommendations for conifer seedbeds (Dow AgroSciences, 2013a, 2013b) and control of dwarf pearlwort (Sagina apetala Ard.) (Dow AgroSciences, 2013b), a similar but annual species compared with birdseye pearlwort (USDA NRCS, 2013); birdseye pearlwort is not listed on the label. The split-plot treatment was oxyfluorfen applied one, two, or three times over germinated larch seeds and the split-split-plot treatment was the rate of those applications: $0,0.28$, 0.42 , and $0.56 \mathrm{~kg}$ a.i./ha. Thus, we installed 192 plots (four preemergence rates by three postemergence applications by four postemergence application rates by four replications) with each plot being $1.2 \mathrm{~m}$ wide $\times 4.6 \mathrm{~m}$ long. A 1.5-m-long buffer was included at the ends of each bed.

On 3 June, the whole plot treatments were applied following label instructions and using a nursery-designed 3-point power takeoff power sprayer calibrated to apply $280 \mathrm{~L} /$ ha at $170 \mathrm{kPa}$ using TeeJet 8006 VisiFlo Even Flat Spray nozzles (TeeJet Technologies, LLC, Wheaton, IL). The first, second, and third postemergence applications were made with the same power sprayer and operator on 7 July, 28 July, and 13 Oct.

Seedlings were grown operationally following established nursery procedures. From June through July, predawn seedling water potential was kept between 0 and $-0.5 \mathrm{MPa}$ through three 45-min irrigation events per week. Beginning in August, seedling moisture stress was increased by reducing irrigation to one or two events per week. Seedlings were fertilized with ammonium sulfate $(21 \mathrm{~N}-$ $0 \mathrm{P}-0 \mathrm{~K})$ at a rate of $47 \mathrm{~kg}$ nitrogen $(\mathrm{N}) / \mathrm{ha}$ on 15 June and ammonium phosphate $(16 \mathrm{~N}-$ $8.7 \mathrm{P}-0 \mathrm{~K})$ at a rate of $36 \mathrm{~kg} \mathrm{~N} / \mathrm{ha}$ on $15 \mathrm{Sept}$.

Measurements. To determine seedling emergence, we placed a $30 \mathrm{~cm} \times 90-\mathrm{cm}$ wide (inside dimensions) polyvinyl chloride frame perpendicular to the seedling rows at the center of each plot $28 \mathrm{~d}$ after sowing (29 June). To facilitate counting, this frame was subdivided into three $30 \mathrm{~cm} \times 30-\mathrm{cm}$ zones and allowed all seven seedling rows to be included. By this time, epigeal germination appeared complete as emerging cotyledons had shed their seedcoats. At the end of the experiment (24 Oct.) the same frames were used to determine the number of live seedlings (final inventory). On 25 Oct., the seedlings at the midpoint of each plot occupying the center three rows for a distance of $30 \mathrm{~cm}$ were carefully excavated to a soil depth of $20 \mathrm{~cm}$. Because the level of pearlwort appeared uniform across treatments, we similarly excavated 10 randomly chosen $30 \mathrm{~cm} \times 30-\mathrm{cm}$ samples near the centers of plots to estimate biomass. Plant samples were sent to the USDA Forest Service Rocky Mountain Research Station in Moscow, ID. For larch, the number of seedlings was recorded per plot, roots were carefully washed, separated from shoots, and tissues (composited within a tissue type for each plot) were dried at $60{ }^{\circ} \mathrm{C}$ to constant weight. Seedling biomass was then calculated as the composited biomass divided by the number of seedlings. For pearlwort, roots were carefully washed but not separated from shoots; the entire plant was dried at $60{ }^{\circ} \mathrm{C}$ to constant weight and the amount of biomass estimated per hectare.
We measured the percentage of each plot covered by bare soil, larch seedlings, and pearlwort during the experiment. Using the frame described previously and similarly positioned, we took digital photographs of the center zone in the frame for each plot before each postemergent application (6 and 27 July and 5 Oct.). We used the methods of Steinfeld et al. (2011) with a $10 \times 10$ grid of circles to determine the extent of coverage in each plot.

Data analysis. For our split-split-plot experiment, we used the PROC GLIMMIX function in SAS (SAS Institute, Cary, NC). Independent variables were preemergence rate, number of postemergence applications, and postemergence rate. Differences in the dependent variables (seedling emergence, final inventory, biomass, and percentage cover of bare soil, larch, and pearlwort) were identified. Type III tests of fixed effects were used to examine interactions and main effects. When the $\mathrm{F}$ test for a given dependent variable was significant at $P \leq 0.05$, we separated means using Tukey-Kramer adjusted for multiple comparisons.

\section{Results and Discussion}

Birdseye pearlwort response. Interactions among the three independent variables (preand postemergence application rate and number of postemergence applications of oxyfluorfen) were absent, but preemergence application rate significantly affected canopy cover. Five weeks after the preemergence application, $\approx 43 \%$ of each control plot was covered by pearlwort, whereas all rates of oxyfluorfen yielded significantly $(P<0.0001)$ less weed coverage, and the highest rate

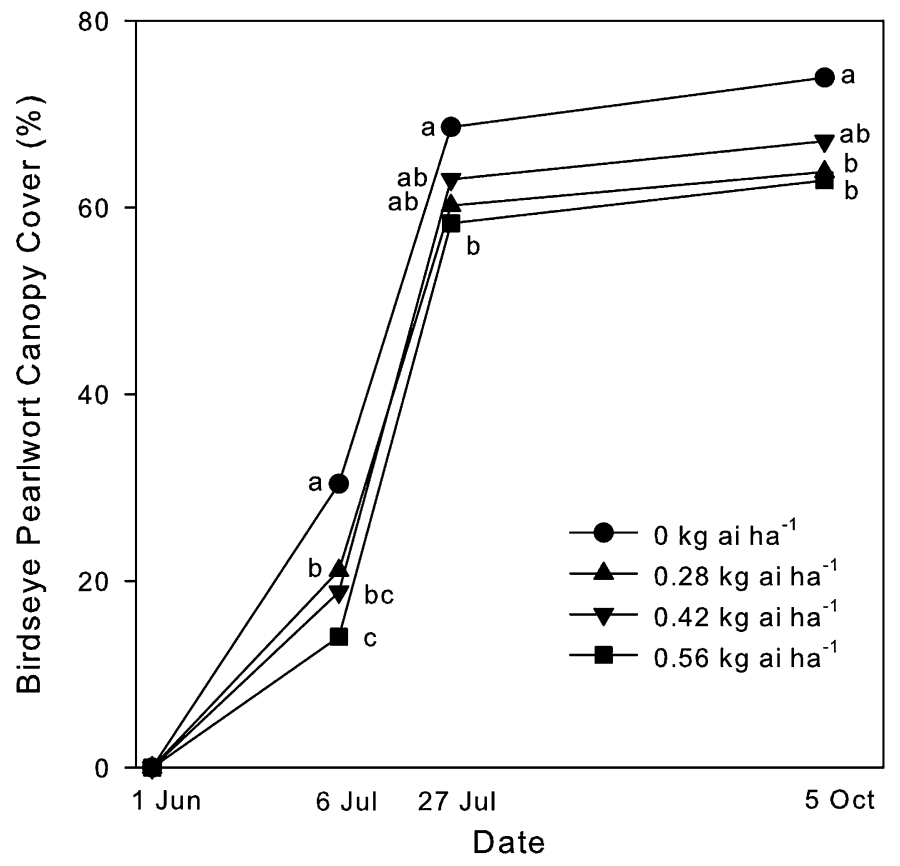

Fig. 1. Percentage of birdseye pearlwort canopy cover during the growing season. Western larch seeds were sown 1 June and canopy cover was assessed 6 July, 27 July, and 5 Oct. immediately before the postemergence applications of oxyfluorfen. Different letters among application rates for each date indicate significantly different values at $\alpha=0.05$. 
(0.56 kg a.i./ha) had half the coverage of pearlwort compared with the control (Fig. 1). This early, relative difference among treatments persisted throughout the production cycle, but the percentage cover of pearlwort at the end of the growing season ranged from $74 \%$ in the control to a significantly lower $(P<$ $0.0001)$, but still unacceptable from a nursery manager's perspective, $63 \%$ when oxyfluorfen was applied (Figs. 1, 2, and 3). Photoplots show that increases in pearlwort canopy were
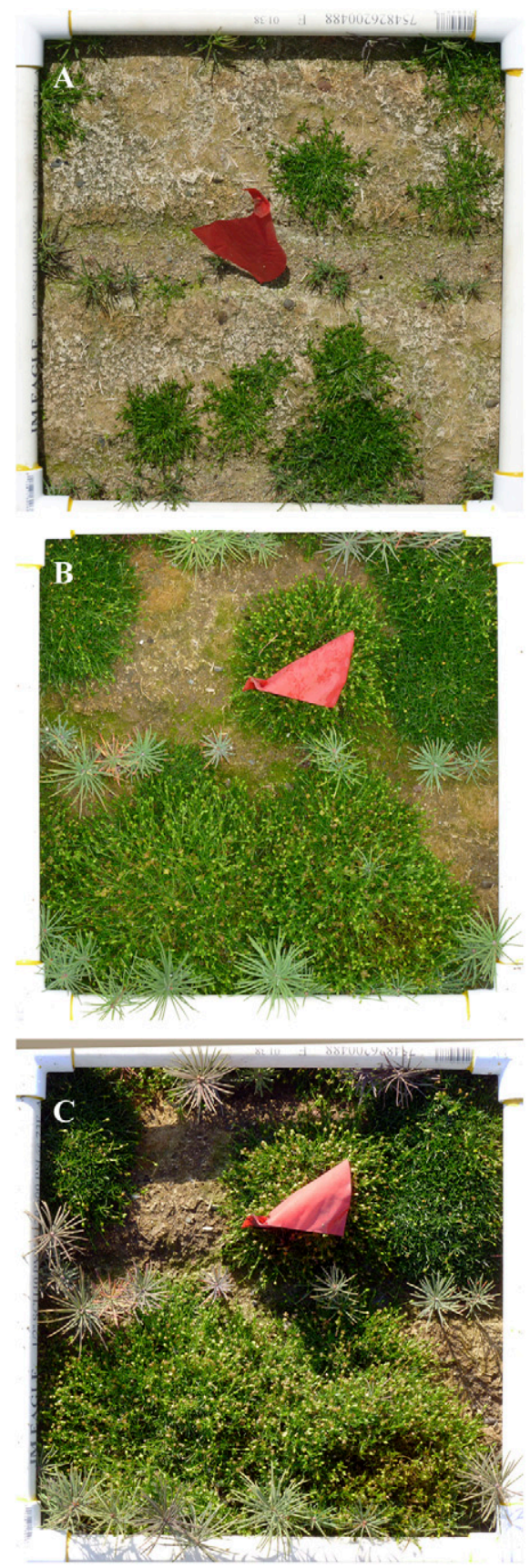

Fig. 2. A series of photos from the center of a single plot treated with $0.28 \mathrm{~kg}$ a.i./ha preemergence and no postemergence applications of oxyfluorfen. Photos were taken 6 July (A), 27 July (B), and 5 Oct. (C) immediately before postemergence applications of oxyfluorfen. Note the expansion of existing birdseye pearlwort plants rather than appearance of new plants. mainly caused by growth of plants that occurred despite application of preemergence oxyfluorfen rather than appearance of additional weeds later in the growing season (Fig. 2). In fact, postemergence oxyfluorfen applied one to three times had no effect on canopy cover (data not shown) and the canopy cover of pearlwort doubled between the first and second postemergence applications (Figs. 1 and 2). The Canadian label for Goal ${ }^{\circledR} 2 \mathrm{XL}$ (Dow AgroSciences, 2013b) indicates that the lowest rate we used $(0.28 \mathrm{~kg}$ a.i./ha) can "suppress" dwarf pearlwort. Although the preemergence applications may initially and statistically "suppress" pearlwort canopy cover, differences rapidly dissipated and were not readily apparent when the plots were viewed in the field at the end of the growing season. Furthermore, pearlwort accounted for greater than $99 \%$ of the non-crop canopy cover and its end-of-season biomass greatly exceeded that of the crop when averaged across all treatments (4000 kg.ha ${ }^{-1}$ vs. $960 \mathrm{~kg} \cdot \mathrm{ha}^{-1}$ ). In container nurseries, better control of pearlwort was realized when oxyfluorfen was combined with oryzalin or pendimethalin (Altland, 2013; Judge et al., 2005).

Western larch response to preemergence applications. Similar to pearlwort, interactions among the three independent variables were absent. Preemergence application rate of oxyfluorfen significantly affected (all $P \leq$ 0.0043 ) every measured dependent variable (Table 1). The two highest preemergence application rates $(0.42$ and $0.56 \mathrm{~kg}$ a.i./ha) reduced emergence $10 \%$ compared with the control ( $0 \mathrm{~kg}$ a.i./ha). The $0.28-\mathrm{kg}$ a.i./ha rate was intermediate, yielding results similar to the control and the two highest rates (Table 1). The fall inventory revealed that the most seedlings were produced in the control treatment and the least occurred in the highest oxyfluorfen rate $(0.56 \mathrm{~kg}$ a.i. $/ \mathrm{ha}, 10 \%$ less than the control) with the 0.28 and $0.42-\mathrm{kg}$ a.i./ha rates being intermediate (similar) to the control and highest rate (Table 1). Seedling root biomass, shoot biomass, and total biomass were, however, significantly greater with increasing preemergence application rate (Table 1). The two highest preemergence application rates $(0.42$ and $0.56 \mathrm{~kg}$ a.i./ha) resulted in an average increase in root, shoot, and total biomass of $32 \%, 41 \%$, and $36 \%$, respectively, compared with the control. Again, the 0.28-kg a.i./ha rate was intermediate, yielding results similar to the control and the $0.42-\mathrm{kg}$ a.i./ha rate (Table 1 ).

In general, oxyfluorfen rates ranging from 0.3 to $1.1 \mathrm{~kg}$ a.i./ha were compatible with a variety of pine species (Abrahamson and Burns, 1979; Gjerstad and South, 1981). Even a preemergence rate of $1.7 \mathrm{~kg}$ a.i./ha failed to harm ponderosa pine (Pinus ponderosa Laws. var. ponderosa), although it did reduce germination of lodgepole pine (Pinus contorta Dougl. var. latifolia Engelm.) (Abrahamson and Burns, 1979). Our rates of Goal ${ }^{\circledR}$ 2XL applied preemergence to larch reflected the acceptable range (1.12 kg a.i./ha or less) provided on the U.S. label for conifer seedbeds, although no Larix species are listed (Dow AgroSciences, 2013a). In contrast, the Canadian version of the label (Dow AgroSciences, 2013b) includes eastern larch [Larix laricina (Du Roi) K. Koch.] and application rates of 0.12 to $0.24 \mathrm{~kg}$ a.i./ha, the maximum rate being similar to our lowest application rate (chemical formulations for the United States and Canada are the same; V. Peterson, personal communication). We noted no

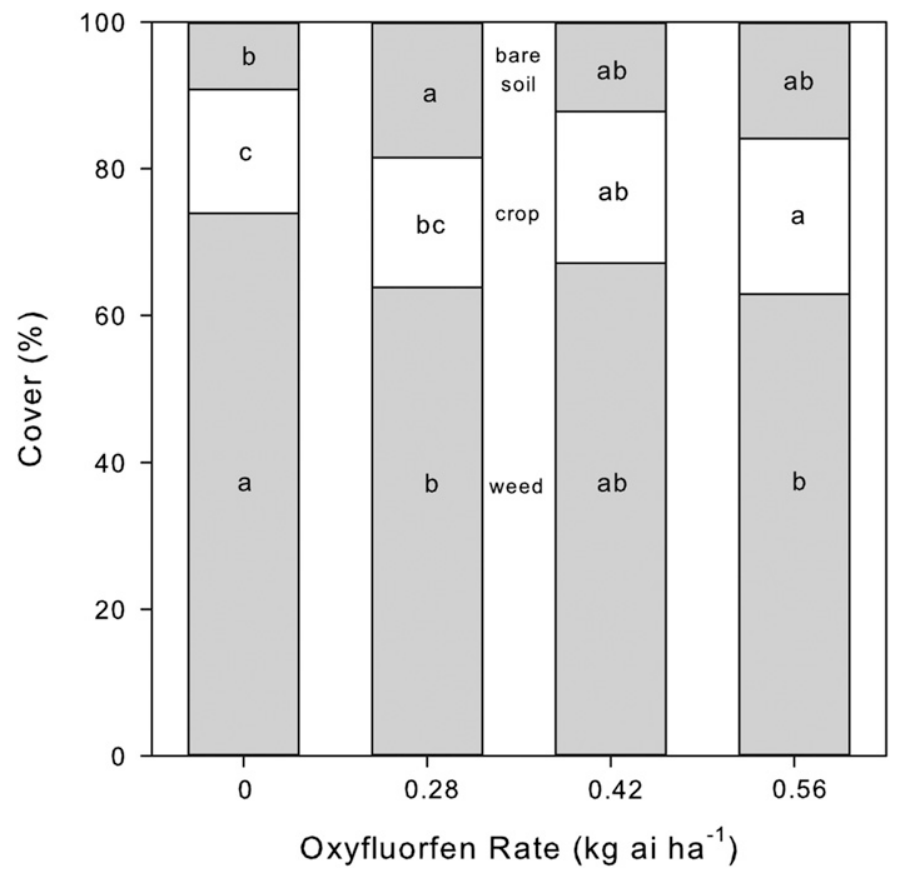

Fig. 3. Percentage of bare soil and western larch and birdseye pearlwort canopy cover at the end of the growing season (5 Oct.) resulting from preemergence applications of oxyfluorfen. Different letters among application rates within a cover category indicate significantly different values at $\alpha=0.05$. 
Table 1. Western larch emergence and growth responses (means and SES) to oxyfluorfen treatments at the U.S. Department of Agricutlure Forest Service nursery in Coeur d'Alene, ID.

\begin{tabular}{|c|c|c|c|c|c|c|c|}
\hline \multicolumn{3}{|c|}{ Oxyfluorfen } & \multicolumn{2}{|c|}{ Seedlings (number $/ \mathrm{m}^{2}$ ) } & \multicolumn{3}{|c|}{ Biomass (g/seedling) } \\
\hline Timing & Rate (kg a.i./ha) & Number of applications & Emerged & Final inventory & Root & Shoot & Total \\
\hline & 0.28 & 1 & $511 \mathrm{ab}$ & $336 \mathrm{ab}$ & $0.138 \mathrm{bc}$ & $0.132 \mathrm{bc}$ & $0.270 \mathrm{bc}$ \\
\hline & 0.42 & 1 & $489 \mathrm{~b}$ & $330 \mathrm{ab}$ & $0.157 \mathrm{ab}$ & $0.158 \mathrm{ab}$ & $0.315 \mathrm{ab}$ \\
\hline SE & & & 12 & 19 & 0.012 & 0.012 & 0.023 \\
\hline Postemergence (A) & & 1 & - & 330 & 0.151 & 0.143 & 0.295 \\
\hline $\mathrm{SE}$ & & & & 18 & 0.011 & 0.012 & 0.022 \\
\hline Postemergence $(\mathrm{P})$ & 0 & 1 to $3^{z}$ & - & $348^{y} a$ & $0.173^{\mathrm{y}} \mathrm{a}$ & $0.166^{y} \mathrm{a}$ & $0.338^{\mathrm{y}} \mathrm{a}$ \\
\hline & 0.28 & 1 to 3 & - & $326 a b$ & $0.144 \mathrm{~b}$ & $0.136 \mathrm{~b}$ & $0.280 \mathrm{~b}$ \\
\hline & 0.42 & 1 to 3 & - & $319 \mathrm{~b}$ & $0.140 \mathrm{~b}$ & $0.146 \mathrm{ab}$ & $0.286 \mathrm{~b}$ \\
\hline & 0.56 & 1 to 3 & - & $315 \mathrm{~b}$ & $0.137 \mathrm{~b}$ & $0.134 \mathrm{~b}$ & $0.271 \mathrm{~b}$ \\
\hline SE & & & & 19 & 0.012 & 0.012 & 0.023 \\
\hline $\mathrm{P}$ & 3 & & - & 0.0060 & 0.0003 & 0.0101 & 0.0010 \\
\hline $\mathrm{R} \times \mathrm{P}$ & 9 & & - & 0.7523 & 0.1886 & 0.2509 & 0.1566 \\
\hline $\mathrm{A} \times \mathrm{P}$ & 6 & & - & 0.5570 & 0.9798 & 0.9003 & 0.9851 \\
\hline $\mathrm{R} \times \mathrm{A} \times \mathrm{P}$ & 18 & & - & 0.6062 & 0.9096 & 0.2122 & 0.5019 \\
\hline
\end{tabular}

${ }^{\mathrm{z}}$ Postemergence (A) was the split-plot (number of applications), and postemergence (P) was the split-split plot (rate of application applied one to three times).

${ }^{\mathrm{y}}$ Mean for each postemergence rate $(\mathrm{P})$ is the average value of all applications.

reduction in any of the dependent variables compared with the control when oxyfluorfen was applied at $0.28 \mathrm{~kg}$ a.i./ha. At preemergence rates $0.42 \mathrm{~kg}$ a.i./ha or greater, however, emergence and final inventory of larch seedlings was significantly reduced compared with the control, whereas biomass was significantly increased. Although increases in growth are associated with decreases in seedbed density, it seems unlikely that all of the $36 \%$ increase in growth is attributable to herbicide-caused decreases in density. Carneiro et al. (2007) found that a $10 \%$ reduction in loblolly pine (Pinus taeda L.) bed density yielded a $3 \%$ increase in biomass and only observed a $30 \%$ increase in biomass when density was greatly reduced (i.e., from 625 to 278 seedlings $/ \mathrm{m}^{2}$ ). Similarly, South et al. (1990) only showed large increases in loblolly pine biomass ( $28 \%$ to $59 \%$ ) when densities were reduced by $\approx 50 \%$. These changes in density are much larger than what we observed (i.e., 350 to 320 seedlings $/ \mathrm{m}^{2}$ ). Instead, it may be that oxyfluorfen had a stimulatory effect on larch. It is well known that hormesis can occur in higher plants receiving sublethal doses of herbicides, and Cedergreen et al. (2007) reported hermaticinduced biomass increases as great as $38 \%$, an amount similar to our observations.

Western larch response to postemergence applications. As with preemergence applications, interactions among the three independent variables were absent. Although none of the dependent variables was affected by the number of postemergence applications of oxyfluorfen (all $P \geq 0.5$ ), they were significantly (all $P \leq 0.01$ ) affected by postemergence rate (Table 1). Similar to the results for preemergence application rate, the two highest postemergence application rates $(0.42$ and $0.56 \mathrm{~kg}$ a.i./ha) reduced the final inventory $\approx 10 \%$ compared with the control. The $0.28-\mathrm{kg}$ a.i./ha rate was intermediate, yielding results similar to the control and the two highest rates. Contrary to results for preemergence application rate, increasing postemergence application rate reduced seedling root, shoot, and total biomass compared with the control an average of $23 \%, 20 \%$, and $21 \%$ among rates, respectively (Table 1). Results were similar for percentage canopy cover (data not shown). This is not surprising because oxyfluorfen is considered to be more active as a postemergence than preemergence herbicide (South and Gjerstad, 1980a). Although low rates of (0.3 and $0.6 \mathrm{~kg}$ a.i./ha) caused no harm to ponderosa pine (Abrahamson and Burns, 1979) or southern pine species (South and Gjerstad, 1980a), they reduced survival of lodgepole pine (Abrahamson and Burns, 1979) and higher rates ( 0.8 and $1.7 \mathrm{~kg}$ a.i./ha) injured blue spruce (Picea pungens Engelm.) (Alspach and Neill, 1980).

In summary, oxyfluorfen $\left(\mathrm{Goal}^{\circledR} 2 \mathrm{XL}\right)$ applied preemergence at $0.28 \mathrm{~kg}$ a.i./ha over larch seeds in a northern Idaho bareroot nursery yielded similar emergence and biomass values as the control. Preemergence rates $0.42 \mathrm{~kg}$ a.i./ha or less yielded similar final inventory numbers as the control, but seedlings exposed to $0.42 \mathrm{~kg}$ a.i./ha or greater had $10 \%$ less emergence and $36 \%$ more total biomass. Postemergence applications, at any rate tested ( 0.28 to $0.56 \mathrm{~kg}$ a.i./ha), reduced larch emergence $10 \%$ and seedling biomass $21 \%$. Although preemergence oxyfluorfen at any rate decreased early canopy cover of pearlwort, and this relative improvement persisted throughout the growing cycle, the overall abundance of this weed (63\% or greater) indicates that oxyfluorfen offers minimal control of pearlwort.

\section{Literature Cited}

Abrahamson, L.P. and K.F. Burns. 1979. Herbicide screening for weed control in western forest nurseries - Great Plains segment. Applied Forestry Research Institute, State University of New York College of Environmental Science and Forestry. Res Rep. p. 15.

Abrahamson, L.P. and T. Jares. 1984. Forest tree nursery herbicide studies in the Lake States and New York: Highlights of research results. Northeast Area Nursery Supervisors Conference Proceedings. 12 Nov. 2013. <http://www.rngr.net/ publications/proceedings $>$.

Akinola, M.O., K. Thompson, and S.H. Hillier. 1998 Development of soil seed banks beneath synthesized meadow communities after seven years of climate manipulation. Seed Sci. Res. 8:493-500.

Alspach, L.K. and G.B. Neill. 1980. Herbicides for Colorado spruce sowings. Rep. Com. Hortic. Res. Can. Hortic. Counc. p. 100-101.

Altland, J. 2006. Little weed, big trouble. Digger 50:23-24, 26-29.

Altland, J. 2013. Weed management in nursery crops. Oregon State University, North Willamette Research \& Extension Center. 7 Nov. 2013. $<$ http://oregonstate.edu/dept/nursery-weeds/ startpage.html $>$.

Boyd, R.J. 1984. Some effects of hexazinone on the germination and survival of northern Rocky Mountain conifer seedlings. Proc. West. Soc. Weed Sci. 37:152.

Carneiro, J.G.A., D.G. Barroso, and L.M.S. Soares. 2007. Growth of bare root Pinus taeda, L. seedlings cultivated under five densities in nursery. Sci. Agr. 64:23-29.

Cedergreen, N., J.C. Streibig, P. Kudsk, S.K. Mathiassen, and S.O. Duke. 2007. The occurrence of hormesis in plants and algae. DoseResponse 5:150-162.

Daugovish, O., S.A. Fennimore, and M.J. Mochizuki. 2008. Integration of oxyfluorfen into strawberry (Fragaria $\times$ ananassa) weed management programs. Weed Technol. 22:685-690.

Doohan, D. and J. Felix. 2012. Crop response and control of common purslane (Portulaca 
oleraceae) and prostrate pigweed (Amaranthus blitoides) in green onion with oxyfluorfen. Weed Technol. 26:714-717.

Dow AgroSciences. 2013a. Goal ${ }^{\circledR} 2$ XL. Dow AgroSciences LLC. 13 Nov. 2013. <http://www. cdms.net/ldat/ld5S1029.pdf>.

Dow AgroSciences. 2013b. Goal ${ }^{\mathrm{TM}}$ 2XL. Dow AgroSciences Canada Inc. 13 Nov. 2013. <http:// www.dowagro.com/ca/prod/goal.htm $>$.

Duncan, C., A. Kulla, and M. Halstvedt. 2008. Effect of aminopyralid on non-target vegetation following aerial application. Proc. West. Soc. Weed Sci. 61:34-35.

FNA [Flora of North America]. 2005. Volume 5: Magnoliophyta: Caryophyllidae. Sagina procumbens. 12 Nov. 2013. <http://www. efloras.org/florataxon.aspx?flora_id=1\&taxon_ $\mathrm{id}=220011873>$.

Gjerstad, D.H. and D.B. South. 1981. Pre-emergence weed-control in loblolly, slash, shortleaf, and eastern white-pine nursery seedbeds. Can. J. For. Res. 11:848-853.

Judge, C.A., J.C. Neal, and R.E. Wooten. 2005. Preemergence control of winter weeds in overwintering ornamental crops. South. Nursery Assoc. Res. Conf. 50:432-434.

Midwest Weeds. 2013. Missouri State University, William H. Darr School of Agricutlure. 6 Nov. 2013. <http://courses.missouristate.edu/ pbtrewatha/Midwest_Weeds.htm $>$.

Pakeman, R.J. and J.L. Small. 2005. The role of seed bank, seed rain and the timing of disturbance in gap regeneration. J. Veg. Sci. 16:121-130.

Salisbury, E. 1976. Exceptional fruitfulness and its biological significance. Philos. T. Roy. Soc. B. 193:455-460.

Schmidt, W.C. and R.C. Shearer. 1990. Larix occidentalis Nutt, p. 160-172. In: Silvics of North America, Vol 1: Conifers. U.S. Department of Agriculture. Forest Service, Agriculture Handbook 654, Washington, DC.

Sloan, J.P. and R.H. Thatcher. 1988. Oxyflourfen shows promise in lodgepole pine seedbeds. Tree Planters' Notes 38(2):3-9.

Soil Survey Staff. 2011. U.S. Department of Agriculture. Natural Resources Conservation Service. Official soil series descriptions. Marble series, revised Feb. 2011. 13 Jan. 2014. <https://
soilseries.sc.egov.usda.gov/OSD_Docs/M/ MARBLE.html>.

South, D.B. 1984. Response of loblolly-pine and sweetgum seedlings to oxyfluorfen. Can. J. For. Res. 14:601-604.

South, D.B. and D.H. Gjerstad. 1980a. Oxyfluorfen: An effective herbicide for southern pine nurseries. South. J. Appl. Forest. 4:36-39.

South, D.B. and D.H. Gjerstad. 1980b. Nursery weed control with herbicides or fumigation: An economic evaluation. South. J. Appl. Forest. $4: 40-45$.

South, D.B., H.S. Larsen, J.N. Boyer, and H.M. Williams. 1990. Seed spacing and seedling biomass: Effect on root growth potential of loblolly pine (Pinus taeda). New For. 4:179192.

Steinfeld, D., J. Kern, G. Gallant, and S. Riley. 2011. Monitoring roadside revegation projects. Native Plants J. 12:269-275.

USDA NRCS [U.S. Department of Agriculture]. Natural Resources Conservation Service. 2013. The PLANTS database. 6 Dec. 2013. <http:// plants.usda.gov>. 